\author{
Research Article \\ (c) 2020 Mimoza Hasani Pllana. \\ This is an open access article licensed under the Creative Commons \\ Attribution-NonCommercial 4.o International License \\ (https://creativecommons.org/licenses/by-nc/4.o/)
}

\title{
Linguistic Forms and Text Functions
}

\author{
Mimoza Hasani Pllana \\ Ph.D. in Philology, \\ University of Sofia, Bulgaria
}

Doi: 10.36941/ajis-2020-0049

\begin{abstract}
Discussions and efforts to separate forms of literary and non-literary texts date from the ancient times, through the works of Plato and Aristotle. In-depth studies are included in Aristotle's Poetics and Rhetoric work. Discussions of this nature continue to exist today, mainly related to language as the most powerful tool for literature, but also for other areas related to literature, such as philosophy, history, journalism and other sciences etc. In this paper we carry out an interdisciplinary research based on theories and practices of literary theory and linguistic, media and cultural research. Our work is based on the comparative methodology through which we research distinctions of a literary text from a non-literary one. Further research queries include defining aesthetic criteria or value, structure, style and other particular elements that distinguish and approximate these types of texts, and also how do we distinguish a literary text from a text that belongs to journalism, history and science spectres.
\end{abstract}

Keywords: Communication, Text functions, Poetic language, Prosaic language, Journalistic language

\section{The Role of Language in Definition of the Writing Style}

Writing styles are created according to the language function. To begin with, writing in literature and any other field is accomplished through language for the purpose of communicating with the reader / audience, to inform the audience, to narrate and persuade as well. The differences that characterize the style and functions are based on the mode of expression, text structure, aesthetic value, meaning or polyphony meaning in literature and other elements that we will see below. The language used in these texts has a wide range, it allows the use of words with direct meaning as well as the use of words with multiple meanings; and this is one of the distinguishing elements of literary and nonliterary writing. Words that do not convey an idea directly and create polyphony of meaning, inevitably belong to literature, while words that convey a clear idea of what they mean create a scientific text which is distinct from literature writing, albeit they are created by the same element of construction, that is language.

Literary writing at first reading is distinct from other forms of writings due to its aesthetic function and its artistic mode of lecture (fiction). Non-literary writing distinguishes itself by striving to achieve scientific, historical, or informational accuracy through strict expressions.

In literary communication, language creates the style and together they support the author in creation of the text, therefore identification of the style as well. Literary writings style allows the author not to use grammar norms and other norms that are usually used in official, scientific, journalistic, legal communication. In these cases an author that doesn't strictly uses certain norms 
creates new texts through language processing that carry out certain messages. This is not the case with the authors of print media texts (newspapers, magazines), broadcast media (television, radio and website), and authors of academic and scientific texts. When we say that all writings are aimed at communicating with the public, we must remember that not all writings can fulfil the function of communication and information. Roland Barthes in his book The Semiotic Challenge (2008, pp 8) sees writing not as a means of communication but as a solid discourse that through its signs imposes the image of a speaker; and that writing opposes speaking about the fact that it is introvert and symbolic. Similar dilemmas are encountered at the level of communication through language as well. Rene Wellek and Austin Warren in Theory of Literature, do not always value everyday language in function of communication. According to them, language is used without communicative purpose as in the case of a child who can speak without a listener nearby, or when an adult can say impractical things (Wellek \& Warren, 2017, pp. 21).

\section{Literary Style}

\subsection{Poetic, prosaic and dramatic language}

Theoretically, interests regarding the organization of language in the function of communication were present since antiquity (Plato in Ferdi dialogue, Aristotle in Rhetoric and Poetics), than medievalism (St. Augustine on Christian Doctrine), up until the recent period of linguistics studies and viewpoints of structuralisms through which language is treated as a structure that transmits messages with supplementary meanings, known as the language of literature realized through signs (semiotics) by marking items without having a natural connection with them (Rrahmani, 2008, pp.25-27). In Aristotle's Poetics and Rhetoric there are discussions on the linguistic functionality of the discourse and its organization, and discussions on issues of poetic discourse. In Poetics, Aristotle says that not every letter / sound can become a comprehensible word unless it is combined with other letters to form nouns, verbs, and sentences; whereas when letters remain only structured as syllables and conjunctions they will not make sense (hence the language does not have a specific function), so according to Aristotle all of the above elements are required to be assembled to establish a functional communication (Aristotle, 1968, pp.76-77) In this context, in this work, Aristotle discusses more about the poetic discourse created by the poet's imitative action by which he is "allowed" to present things as they were or are, as they were supposed to be, or as they should be (Aristotle, 1968, pp.11-12). An example; during the process of creation / imitation, poets known as descriptors manage to create the image of a photograph by describing every detail, as an imitation harmony, known from ancient times, as the rhetorical tool (opsis) that Aristotle used to describe suffering of Sisyphus as the stone rolls off the rock (Frye, 1990, pp.349-350). Otherwise, when these rhetorical tools are used in the style of literary writing, they create an imitative harmony, as exemplified by the description of the sounds, noises of living beings, or natural phenomena that literary theorist Northrop Frye illustrates this form of the imitation in his work Anatomy of Criticism: Four essays (1990, p.351-352) with verses in the Fairy Queen:

For else my feeble vessel crazed, and crack

Through thy strong Buffets and Outrageous blows,

Cannot endure, but needs it must be wrack

On the rough rocks, or on the sandy shallows.

Generally, literary writing is represented through three accepted literary genres: epic, lyric and dramatic. Poetry from the beginning of creation has been organized in verses in the long form as epic poetry and in short form as lyric poetry (ballad, epigram, epitaph, charm, idyll, anthem, ode, sonnets, etc.). In all forms, poetry is also distinguished for its semantic linguistic function, for rhythm and 
writing in the first person, though semantic language and rhythm are also present in prose. The literary writing in prose is accomplished through sentences into long phrases, which are written one after the other, telling the story (through the narrator in the third person and in the first person). In addition to the narrator, the rest of the prose is constructed through monologues and personage dialogues. Poetic language, in addition to the figurative function and polyphonic meaning, creates rhythmic pronunciation and manages to influence the emotions of the reader. The greater power of poetic language rests on the figure and the ability it gives to the author to say another thing through a word which in the ordinary sense does not say the same thing. Poets themselves empower the poetic language and its role in the poetry. Well-known French poet Stéphane Mallarmé puts the poetic word over the idea, noting that you do not make a poem with ideas, but with words. Further, Mallarmé in poetry values the double role of the word, and its multiple meaning (Wayland-Smith, 2002). The most popular stylistic figures that create multiple meanings of the word are: metaphor, symbol, comparison, allegory, irony, satire, sarcasm, personification, metonymy, paradox, onomatopoeia, hyperbole etc. In literary prose writings, the characters' dialogue is also important for the fact that they create artistic and emotional connections with the reader and make him bear in mind the character of the literary personage. The prose dialogue helps the reader to create an image for the character as well as real-life dialogue. However, dialogue is not powerful enough to create the image of a literary personage, if it were not complementary elements such as description, expression of feelings, action, etc. We will test the function of these elements in a dialogue developed in the work Broken April ${ }^{1}$, by renowned Albanian author Ismail Kadare:

That's not so far from here. If you step along you can be home tonight? “

"And you?" Gjorg asked.

"Oh, I' $m$ from very far from here, from the Krasniq banner."

Gjorgj whistled. "Yes, that's really far. You'll certainly have sold your bull before you get home."

"I don't think so. Now the only places where I can sell him are the roads that are under the bessa" and they're scarce."

Gjorgj nodded. "You see, if this road that's under the besa went as far as the crossing with the Grand Road of the Banners nearby?"

"It's not far. That's what I call road! What don't you see go by there!" (Kadare, 2003, p.213).

The narrator is the person who tells the story and is one of the important elements of literary writing in the form of prose, as it directly affects the meaning of the story. The most pronounced narrator in literary prose is the one in the third person (he). This narrator performs the narrative from the objective position, avoiding direct assessment, giving the reader to carry out the assessment directly. In general, the narrator, from the third person talks about a well-known and completed event creating a distance with the reader. Whereas, when the narrative is developed in the first person, this creates stronger emotional bonds with the reader for the fact that there is no distance between the narrator and the narrative, creating the possibility for the reader to feel and get attracted from the closeness and manifestation of the subjectivities presented by confession in the first person (Rrahmani, 2008, p.72-75). The following text presents the narrative in the third person:

Gjorgj did not answer. An hour's walk from here, he told himself. He raised his head to look for the sun's track behind the clouds. He reckoned that there were still two hours of daylight left. She had never been so near. He would be able to see his fairy (Kadare, 2003, p.214).

Within the style of literary writing, the genre of drama is also included. Dramatic writing has a

\footnotetext{
${ }^{1}$ Published originally in 1978

${ }^{2}$ Besa, in Albanian culture is the meaning of keeping the promise. But in this book, besa used in the context of revenge.
} 
distinctive element from the first two genres, which is the conflict developed by the characters in the form of dialogue. The language used has emotional loads as a function of drama development. The form of writing is verse and prose, while in antiquity the form of playwritings was realized through verse writing. Despite the elements mentioned for the linguistic and structural organization of poetry and prose, we cannot say that they are definitive defining elements.

There are well-known works that transcended these differences and broke the boundaries of organization, which means that the definition can be based on their content, understanding their literality as prose and poetic literality (Rrahmani, 2008, p.150-151). In all three literary genres, language is selective and has high semiotic values. The function of semiotic language is to create the meaning of literary writing.

\section{Non-Literary Style}

\subsection{Scientific, historic, journalistic language}

Non-literary writing encompasses all styles where language does not have a stylistic, multifaceted function, but scientific, historical, philosophical, journalistic, conversational and other functions of similar nature. Non-literary writings are challenging to accomplish, as they must be crafted according to linguistic norms recognized by the majority of the population, or by target groups. Therefore the first distinguishing element of non-literary writing is the linguistic function.

When language performs a scientific function, then it is a non-literary, science-style text. This style of writing requires careful word choice to give a certain meaning excluding any dilemma for the meaning of the word used, and in some cases, scientific language, in certain disciplines, reduces words by using symbols and signs. Scientific writing includes textbooks and academic papers, dissertations, academic journals, translations, papers and similar forms of writing. When we analyse structural, thematic and stylistic language of academic writing research, we find that the audience has expectations which relate to accuracy, originality, thoughtfulness and even passion, but according to research results, there are very often academic writings that don't offer the expected clarity and are often ambiguous (Bacon, 2015).

The style of historical writing is distinguished by the use of longer words that describe historical data and events. The words used accurately convey the ideas, evidence, and historical data of the authors from various periods. Historical writings are distinguished for their accuracy, analytical approach, and detailed descriptions. University professors Wrigglesworth \& Mckeever (2010) believe that the prerequisite for writing history is knowledge of the sciences of humanities and arts, meaning that writing about history is utilizing an extensive linguistic and academic knowledge. In-depth studies of this nature focus on research question: how does language help text achieve specific communicational purposes? Authors say that writing historic texts is quite specific as this requires language and literary related skills. Combining skills, academic socialization and academic literature was decisive in development of various approaches of teaching writing in higher education in the United Kingdom. According to this tradition developed in certain historical political contexts some literary practices were embedded and some were excluded (Wrigglesworth \& McKeever, 2010). Further, the researchers conclude that "interdisciplinary work goes beyond what any discipline can achieve on its own in meeting needs"(Wrigglesworth \& McKeever, 2010), Below an example of a short historical writing:

Benjamin Franklin (1706-179o), was a publisher, scientist, inventor, diplomat, writer and one of the signatories of the Declaration of Independence from late 1776 until 1785, he was American Commissioner in Paris...Franklin, became the sixth President of the Supreme Executive Council of Pennsylvania in 1785...(Beare, 2009, p.217).

The style of writing in journalism is one of the styles of continuous evolution. It applies to print 
media (newspapers, magazines and print media online) and broadcast media (television, radio and online broadcast media). The essential function of journalistic writing is to inform, educate, sensitize and entertain the audience (viewer/reader). As an example, we have chosen a short informative text from one of the largest news agencies in the world, The Associated Press:

One of the world's rarest coins, a gold piece bearing the image of Britain's King Edward VIII before his abdication, has sold for 1 million pounds (\$1.3 million), setting a new record for a British coin. The historical oddity shows Edward, the uncle of Queen Elizabeth II, before he relinquished the throne in 1936 to marry American divorcee Wallis Simpson.....(The Associated Press, 2020).

The style of writing in journalism in the century we live in fails to exclude the role and power of visual rhetoric that has become an indispensable part of all types of media. Therefore, it is estimated that combining the written word with visual aids, especially photography, would create opportunities for clarity of image and clarity of the author's opinion which means that the combination of word and image would create an ideal communication (Marchino, 2014, p.96 ). More specifically, in terms of structure and function, journalistic writing has a unique structure that means the following: planning, construction and elaboration. Journalistic reporting must include reliable new information modelled and filtered through a complex process before it reaches the media.

All of these non-literary writing adhere to literature and become functional in literary writing as well, whereas the use of non-literary content is determined usually by literary demand. Transporting non-literary text to literature text requires for word processing to derive their new function, to create a text that has not only a semantic dimension but a semantic polyphony. Non-literary writing, when used in literary work, expresses a new meaning while subject to a new rule of linguistic organization. In literature, this function is performed by the author, in accordance with the requirements of artistic motivation (Rrahmani, 2008, p.30-31). In conclusion, all types of writings are intended for communication and information, but they differ in how they use language to transmit selected messages. Direct communication (scientific, journalistic, historical, philosophical, etc.) through messages reveals true intentions, ideas, needs and desires, whereas in indirect communication (literary writings), messages do not directly transmit real ideas and intentions, but through stylistic words (Martin \& Nakayama, 2010, p.158).

\section{Conclusion}

As we noted, language is a tool for building all texts with and without literary function. The literary and non-literary texts are separated by the boundary of the purpose-defined language function. There are two text objectives: the first objective of the text is to establish communication through words previously known but used for a new meaning in order to transmit the message indirectly, while the second objective is to use simple words and to make the meaning as clear as possible. All types of writings are aimed at communicating with the reader; in this case non-fiction writing is aimed at direct communication, while literary writing is more about communicating through symbolisms.

\section{References}

Aristotle (1968). Poetics. Publishing Entity of the Socialist Republic of Serbia. Barthes, R. (2008). The Semiotic Challenge. Dukagjini publishing Peje.

Beare, E. (2009). 501 Must-Know Speeches. Bounty Books London.

Bacon, N. (2015). Review Essay: Cross-Disciplinary Approaches to Style. College Composition and Communication $67 \quad(2)$ : $\quad$ p. 290-303, retrieved from https://search-proquestcom.sheffield.idm.oclc.org/docview/1749628296?rfr_id=info\%3Axri\%2Fsid\%3Aprimo

Frye, N. (1990). Anatomy of Criticism. Rilindja Prishtine.

Kadare, I. (2003). Broken April. Vintage Books London. 
Marchino, S. C. (2014).Theory and Techniques of the Radio-Television Language-Political Publicity in Television. Center for Excellence in Journalism Tirane.

Martin, J. N.\&Nakayama, Th. K. (2010). Introduction to Intercultural Communication. UET Press Tirane.

Rrahmani, Z. (2008). Theory of Literature. Faik Konica.

The Associated Press (January 2020). Rare coin of Britain’s King Edward VIII fetches record \$1.3M. Retrieved from https://apnews.com/c641502744b2417ofiz8ad3f789d7f9e

Wrigglesworth, J. \& McKeever, M. (2010). Writing History: A genre-based, interdisciplinary approach linking disciplines, language and academic skills. Arts and Humanities in Higher Education, 9 (1): p. 109 - 123. Retrieved from https://doi.org/10.1177/1474022209349987

Wayland-Smith, E (2002). Passing Fashion: Mallarme and the Future of Poetry in the Age of Mechanical Reproduction. $M L N 117$ (4), p. 887-907. doi:10.1353/mln.202.0068

Wellek, R. \& Warren, A. (2017). Theory of Literature. Onufri Tirane. 